\title{
Residual Capacity of Corroded Reinforced Concrete Bridge Components:
}

\section{A State-of-the-Art Review}

\author{
Mohammad M Kashani ${ }^{1}$, Jake Maddocks ${ }^{2}$,Ebrahim Afsar Dizaj ${ }^{3}$
}

\section{Abstract}

The current paper provides a comprehensive review of experimental studies on corrosion damaged reinforced concrete (RC) components, and the ability of current state-of-the-art numerical models to predict the residual capacity of these corroded RC components. The experimental studies on corroded RC components are classified into five different categories including: (i) beams in flexure, (ii) beams in shear, (iii) columns under pure axial compression, $(i v)$ circular columns in flexure, and (v) rectangular columns in flexure. For each group, a summary of all the previous research are provided. Through the regression analyses, the experimental results of each abovementioned groups are used to examine the adverse effect of corrosion on ductility and, flexural, shear, and axial capacity loss of the corroded RC components. Finally, the observed results of the previous experimental studies are compared with the predicted values using the state-of-the-art numerical models currently available in the literature. The summarised experimental results show that corrosion has much more adverse impact on ductility of the RC columns than strength. However, the effect of corrosion on ductility and strength reduction of $\mathrm{RC}$ beams is the same. Moreover, results of cross-sectional moment-curvature analyses using the state-of-the-art corrosion damage models show a good correlation between the predicted residual flexural capacity and observed experimental results. Finally, the existing shortcomings in the literature and open issues to be addressed in the future research are discussed, and some recommendations are provided.

Keywords: Corrosion; residual capacity; ductility loss; RC component; numerical modelling

\footnotetext{
${ }^{1}$ Associate Professor, Faculty of Engineering and Physical Sciences, University of Southampton, Southampton, SO17 1BJ, United Kingdom (corresponding author), Email: mehdi.kashani@soton.ac.uk

${ }^{2}$ MEng Student, Faculty of Engineering and the Environment, University of Southampton

${ }^{3} \mathrm{PhD}$ in Structural Engineering, University of Guilan, Email: ebrahim_afsar@live.com
} 
Bridges are recognised as the most important elements of any transport infrastructure network, which result in a severe corruption in functionality of the entire network if they are disabled. There is an enormous amount of ageing major bridges that are in service in earthquake prone regions (ASCE, 2013; Ghosh and Padgett, 2010). To advance a reliable solution, the safety, functionality and the service life of bridges must be estimated using a systematic mathematical approach.

Ageing reinforced concrete (RC) bridges are susceptible to various environmental stressors including chlorideinduced corrosion and carbonation. Chloride-induced corrosion of reinforcing steel is a major environmental stressor affecting the performance of ageing RC bridges and structures in the UK, USA and other developed countries (Rao et al., 2016a; Chiu et al., 2015). Severe corrosion can result in catastrophic failure (Broomfield, 2007). In the UK, corrosion damage to highway bridges is estimated to cost about $£ 1$ billion/year in England and Wales alone (Wallbank, 1989) (this is approximately $10 \%$ of the total bridges in the UK). In the US, the estimated cost to repair or replace corroded RC bridges is about $\$ 150$ billion (Transportation Research Board, 1991).

Over the past few decades several researchers have put a significant effort in studying the impact of corrosion on the nonlinear behaviour of corroded structural components (beams, slabs and columns) using accelerated corrosion procedure in the laboratory (Cairns and Zhao 1993; Rodriguez et al. 1996; Rodriguez et al. 1997; Razak and Choi 2001; Cairns et al. 2005; Rodriguez et al. 2005; Du et al 2007; Azad et al. 2007). The principal effects of corrosion on structural elements are: $(i)$ loss of reinforcement cross section, (ii) changing the mechanical properties and ductility of reinforcement, (iii) reduced compressive strength of the cracked cover concrete, and (iv) reduction of bond strength at the reinforcement and concrete interface ( $\mathrm{Vu}$ et al., 2016). The progressive expansion of rust at the reinforcement and concrete interface induces splitting stresses in concrete and eventually leads to cover cracking and spalling (Vidal et al., 2004). This will weaken the bond strength between steel and concrete, which will influence the bending stiffness and the shear capacity of the structural element (Rodriguez et al. 1996; Chung et al. 2008a; Yoon et al. 2000; Malumbela et al. 2009). Moreover, pitting corrosion causes localised cross section loss, which results in degradation of ductility and strength of the corroded reinforcing bars. Therefore, corrosion induced mechanical damage at material level (concrete, steel and bond strength) will lead to diminished structural performance of RC elements and will subsequently affect the global response of the structural system. 
In recent years researchers have conducted several experimental studies exploring the impact of pitting corrosion on residual capacity, ductility loss, inelastic buckling, and low-cycle fatigue behaviour of corroded reinforcing bars (Palsson and Mirza 2002; Cairns et al. 2005; Almusallam 2001; Du et al. 2005a, b; Apostolopoulos et al. 2006; Alexopoulos et al. 2007; Apostolopoulos and Michalopoulos 2007; Papadopoulos et al. 2007; Apostolopoulos and Papadopoulos 2007; Apostolopoulos and Pasialis 2008; Apostolopoulos and Koutsoukos 2008; Apostolopoulos and Papadakis 2008; Apostolopoulos 2009; Lee and Cho 2009; Kashani et al., 2013a, 2013b, 2015a, Fernandez et al., 2015).

A significant number of studies have been dedicated to investigating the nonlinear behaviour of corrosion damaged RC beams and slabs under vertical loading (Rodriguez et al. 1997; Cairns and Zhao 1993; Rodriguez et al. 1996; Razak and Choi 2001; Cairns et al. 2005; Rodriguez et al. 2005; Du et al 2007; Azad et al. 2007). In recent years, several researchers have also employed nonlinear finite element analysis to study the adverse influence of corrosion on the structural response of RC beams (Coronelli and Gambarova 2004; El Maaddawy et al. 2005a; Kallias 2011). Most of the early numerical and experimental studies have been focused on the structural response of RC beams and slabs under monotonic loading. However, there is a large number of RC bridges and structures that are located in environmentally aggressive and high seismicity regions. Therefore, recently, researchers have started to investigate the influence of corrosion on the nonlinear behaviour of RC beams, columns, and frames under cyclic loading (Pantazopoulou et al. 2001; Aquino 2002; Tastani et al. 2004; Bousias et al. 2004; Belarbi and Bae 2007 Ou et al., 2011; Meda et al., 2014; Li et al., 2015; Liu et al., 2017).

More recently, several researchers have studied the influence of corrosion on seismic performance, fragility and the life-cycle cost analysis of deteriorating structures and bridges (Stewart, 2004; Choe et al. 2008; Berto et al. 2009; Ghosh and Padgett 2010; Choe et al. 2009; Akiyama et al. 2011; Simon et al. 2010; Akiyama and Frangopol 2013; Alipour et al. 2011; Biondini et al. 2014 ,Ou et al. 2013, Guo et al., 2015a; Ni Choine et al., 2016; Rao et al., 2016b; Ghosh et al., 2016; Cui et al., 2018). The results of these studies showed that corrosion significantly affects the seismic vulnerability of RC structures and bridges. In these studies, fibre-based nonlinear finite element programmes (e.g. OpenSees (McKenna, 2011)), have been used for the analysis.

According to the aforementioned studies, it is evident that a significant effort has been put to investigate and quantify the impact of material deterioration on structural and seismic performance of corroded RC components and bridges. Despite all these previous studies in investigating the impact of corrosion of reinforcement on 
structural performance of RC structures and bridges, it is still an open issue, and requires a significant research in the future. This is due to the complexity in quantification of corrosion of reinforcing bars inside concrete, and random nature of corrosion, which result in significant uncertainties in numerical models and performance prediction.

Currently, there is no concise paper available in the literature to review the state-of-the-art research and highlights the needs for future research. Accordingly, the aim of this paper is to provide a critical review of the previous experimental testing and the available state-of-the-art numerical models for structural performance evaluation of corroded RC components. To this end, the results of the previous experimental studies are used to investigate the effects of corrosion on strength and ductility loss, and failure mechanisms of corroded RC components. Furthermore, an exemplary comparison has been made between the observed experimental results and the current state-of-the-art numerical models for predicting the residual flexural strength of corroded RC components. Finally, the current shortcomings in the literature are identified, and some recommendations to address the open issues in future research are provided. It should be noted that the details of all the experimental data and computed values are provided in two downloadable Excel files (Comp Vs Exp. xlsx and Exp data.xlsx) as the online supplementary.

\section{Experimental Investigation of Structural Performance of Corroded RC Beams}

\section{Adverse effect of corrosion on structural performance of RC beams in flexure}

A summary of all the experimental studies on corroded Rectangular RC Beams in Flexure (RRBF) and their outcomes is provided in Table 1. In this table, $\psi_{l}$ is the average percentage of mass loss of longitudinal reinforcements. Several researchers (Tables 1) conducted experimental testing to study the effect of corrosion on nonlinear flexural behaviour of RC beams. All these studies agree that corrosion of longitudinal reinforcements has a significant influence on the failure mode of RC beams. In this section, the key common findings of these experimental studies are provided.

Using an accelerated corrosion procedure, Mangat and Elgarf (1999) carried out a set of experimental testing on corrosion damaged RC beams subjected to pure flexural loading. They investigated the influence of corrosion rate on the strength and ductility of the tested specimens, and found that $10 \%$ of mass loss of longitudinal reinforcement with corrosion rate of $2 \mathrm{~mA} / \mathrm{cm}^{2}$ results in about $60 \%$ reduction in flexural capacity and $77 \%$ reduction in ductility. However, another corroded beam with $10 \%$ of mass loss of longitudinal reinforcement 
with rate of $4 \mathrm{~mA} / \mathrm{cm}^{2}$ resulted in about $70 \%$ reduction in flexural capacity and $77 \%$ reduction in ductility. This is because higher corrosion rate has more significant impact on degradation of concrete, and subsequently results in a more reduction in strength.

Castel et al. (2000) conducted experimental testing on uncorroded and 14 years old corroded RC beams under flexural loading. They found that about $20 \%$ corrosion results in about $35 \%$ reduction in flexural stiffness and about $70 \%$ reduction in ductility of corroded RC beams. They found that the residual flexural strength of corroded $\mathrm{RC}$ beams is primarily a function of mass loss of tensile reinforcement, and is not significantly affected by loss of bond strength.

El Maaddawy et al. (2005b) conducted a set of experimental testing on pristine and corroded RC beams. The tested specimens were corroded using accelerated corrosion procedure and a sustained load to represent the service load on the structure. The sustained load on the beam resulted in flexural cracks, which subsequently resulted in accelerating the corrosion-induced material degradation. They reported that the rate of corrosioninduced concrete cover cracking increased by about $22 \%$ in the loaded beam in comparison to unloaded beam. They found that there is a linear relationship between cross sectional area loss of tensile reinforcement and residual flexural strength of corroded RC beams. However, corrosion had a more significant influence on ductility of corrosion damaged RC beams with mass loss ratios greater than $15 \%$, where severe pitting in corroded reinforcement were formed.

Torres-Acosta et al. (2006) identified that maximum pitting depth has the greatest impact on the load capacity, rather than the average corrosion penetration in relation to the reinforcement radius. They also reported that corrosion-induced concrete cracking is larger in dry environments, despite a wet setting accelerating pit creation on the reinforcement exterior. The experimental results showed that about $10 \%$ reduction in the average corrosion penetration over initial longitudinal reinforcement radius resulted in $60 \%$ reduction of the flexural strength of RC beam.

$\mathrm{Du}$ et al. (2007) conducted experimental testing on corroded and uncorroded RC beams with various reinforcement details under pure flexural loading. They used accelerated corrosion procedure to corrode the specimens. The experimental testing included over-reinforced, balanced-reinforced, under-reinforced, and very under-reinforced RC beams. They reported that corrosion changes the failure mode of over-reinforced beams from brittle failure to a less brittle and even ductile failure mode, but reduces the ductility of under-reinforced 
beams to fail in a less ductile or even a very brittle manner. They also found that corrosion mass loss more than $10 \%$ results in premature fracture of tensile reinforcement in very under-reinforced beams, which results in severe reduction of ductility in these beams.

Cairns et al. (2008) conducted a set of experimental testing on RC beams with high-ductility plain round bars, with about 4\%-10\% cross-sectional area loss of reinforcement (lightly corroded). They observed that corrosion changes the failure mechanism of RC beams from flexure to flexure followed by local bond-slip failure of reinforcement. They found that the flexural strength of corroded beams is higher than uncorroded specimens. This is primarily due to an increase in the anchorage strength, to be associated primarily with increased radial stresses on the reinforcement-concrete interface near the end supports.

Azad et al. (2007) and (2010), conducted experimental testing on corroded and uncorroded RC beams under pure flexural loading with different cross-sectional sizes and bar diameters. They found that in lightly corroded RC beams (less than $10 \%$ of mass loss), the reduction of bar diameter is the most important factor affecting the residual flexural strength of corroded RC beams. However, as corrosion increases, the pitting corrosion effects, loss of bond strength and damage in concrete have significant contribution in residual flexural strength of corroded RC beams. Their research output showed that corrosion damaged beams experiences higher deflection in comparison to uncorrded beams, which is due to loss of flexural stiffness. They also reported that the percentage of mass loss of steel is smaller for larger diameter bars compared with that of smaller bar diameters.

Ou et al. (2012) conducted a number of cyclic tests on large scale cantilever beams. One of the specimens was used as an uncorroded control specimen and other four specimens were corroded with varied percentage of mass losses including $1.7 \%, 3.08 \%, 4.08 \%$ and $8.03 \%$. The uncorroded beams and the beams with different corrosion durations including $12.5,25$, and 50 days (specimens with $1.7 \%, 3.08 \%$ and $4.08 \%$ mass loss respectively) were failed in the flexure. The flexural cracks initiated on the top and bottom faces of the beams, and as the drift increased, cracks propagated through the thickness of the section. The cover concrete spalled off at about 3\% drift. The main reinforcement (longitudinal) started to show a significant inelastic buckling at 5\% drift and subsequently resulted in crushing of core concrete which eventually led to beam failure. For the specimens with low level corrosion from $0 \%$ to $4.08 \%$ of mass loss, the maximum applied force reached at about $4 \%$ drift. The combined influence of core concrete crushing and buckling of longitudinal reinforcement resulted in a significant reduction in load capacity beyond the $4 \%$ drift. The fracture of reinforcement was not observed in the 
experiments. However, as the level of corrosion increased to $8.03 \%$, the mode of failure changed from flexural failure to flexural-shear failure. The envelope response of this specimen shows that the maximum strength was reached at $0.8 \%$ drift. Significant softening type behaviour observed once the third hoop fractured at about $2.5 \%$ drift.

The results of various experiments performed by Zhu and François (2014, 2015) and Zhu et al. (2013) showed that about $1 \%$ loss in cross-sectional area of longitudinal reinforcement leads to about $1 \%$ decrease in relative yield strength and $0.85 \%$ reduction in ultimate capacity. However, this was found to be the result of the concrete crushing. The five beams for the experiments were cast in 1984; three of which were kept in a chloride environment, one in a chloride environment under applied loading and another one experienced corrosion simulation via notches.

Yu et al. (2015) conducted a similar experiment to Zhu and François (2014, 2015), with the same dimensions, loading conditions and cover thickness as the 1984 samples. The control beam failed by compressive concrete crushing accompanied with the fracture of both rebar near the middle of the beam. This was after the formation of four cracks beginning at the tensile zone and extending to the compressive zone. On the other hand, the corroded RC beam also formed cracks from the tensile to compressive zone which rapidly increased in width until the beam failed via fracture of a single tensile bar, $75 \mathrm{~mm}$ away from the centre, which confirms corrosion does alter the failure mode. Yu et al. (2015) concluded that corrosion longitudinal reinforcement in RC beams has a significant impact on the ductile failure mode, but does not have a great impact on yield and ultimate strength of RC beams.

Al-Saidy et al. (2016) conducted a set of experimental testing on corroded RC beams in flexure with and without any shear reinforcement (stirrups). They reported that corroded beams without shear reinforcement fail in a very brittle manner, with about $60 \%$ reduction in the maximum deflection. This was due to premature bond failure of the longitudinal reinforcement. The corroded beams with shear reinforcement had some reduction in flexural strength but failed in a more ductile manner. They reported that corroded beams with $5 \%$ and $7.5 \%$ of mass have about $1 \%$ and $25 \%$ reduction in the maximum deflections respectively.

In order to draw a conclusion on the abovementioned experimental results, the ratio of residual ultimate bending moment strength and the ratio of residual ultimate deformation of each beam specimen is plotted against the corresponding percentage of mass loss, $\psi_{l}$ (Fig. 1). The residual ultimate bending moment ratio is defined herein 
as the ratio of bending moment strength of each tested corroded beam $\left(M_{u, c o r r}\right)$ to its corresponding uncorroded beam $\left(M_{u, 0}\right)$. Similarly, the residual maximum deformation ratio is defined as the ratio of maximum deflection of each corroded beam to its corresponding uncorroded beam.

Fig. 1 shows that both the residual ultimate moment ratio and residual maximum deformation ratio follow a linear trend, considering all the experimental results. However, the results are highly scattered due to considering various experiments with different scenarios. It worth noting that, the number of data points in Fig. 1(b) is less than that of Fig. 1(a) as in some studies the maximum deflections of the tested specimens have not reported.

\section{Adverse effect of corrosion on structural performance of RC beams in shear}

Table 2 summarises all the previous experimental studies on structural response of corroded Rectangular RC Beams in Shear (RRBS). In this table, $\psi_{t}$ is the average percentage of mass loss of shear reinforcement (stirrups). Higgins and Farrow III (2006) conducted experimental testing on corroded RC beams with three types of crosssectional geometry, such as rectangular, Inverted-T, and T sections. They only corroded the shear reinforcement (stirrups) using accelerated corrosion technique. The longitudinal reinforcement was epoxy coated, and hence, remained uncorroded. For each group, a control specimen and three corrosion levels (corrosion at shear reinforcement only) including, light damage with about $12 \%$ of mass loss, moderate damage with about $20 \%$ of mass loss, and severe with about $40 \%$ of mass loss were considered. They reported that diagonal shear cracking of concrete normally arisen in beams at low amplitude loading. However, corroded stirrups could not sustain and constrain shear cracks. Therefore, RC beams with severe corrosion of shear reinforcement corrosion (often highly localised pitting corrosion) will fail in a very brittle manner following the initiation of diagonal shear cracks in concrete.

Suffern et al. (2010) conducted experimental testing to investigate the nonlinear behaviour of disturbed regions with corroded stirrups in RC deep beams. They reported that corrosion rates up to about $20 \%$ results in approximately 53\% reduction in shear strength of corroded deep beams. They also reported that increasing the shear span-to-depth ratio of beams results in further reduction in shear strength of corroded beams

Xia et al. (2011) carried out experimental testing on uncorroded and corroded RC beams to investigate the shear behaviour of RC beams with corrosion damaged shear reinforcement. They found that corrosion changes the shear failure mechanism of corroded beams. The shear failure of uncorroded beams was initiated by concrete crushing in compression. However, shear failure of corroded beams initiated by fracture of shear reinforcement 
218 (stirrups). Corrosion of shear reinforcement greater than $10 \%$ resulted in a significant reduction on in shear 219 capacity of corroded RC beams.

220 Alaskar (2013) tested seventeen RC beams considering different shear reinforcement types, corrosion mass loss ratios, and repair availability. The longitudinal reinforcement was epoxy coated to be prevented from corrosion, and only transverse reinforcement were corroded using accelerated corrosion technique. They reported that low level of corrosion (up to $8 \%$ of mass loss) results in an increase in shear capacity of corroded beams in comparison to uncorroded specimens. However, for mass loss ratios beyond $8 \%$ almost a linear reduction in shear strength of corroded beams observed ( $15.6 \%$ of mass loss resulted in $14.4 \%$ shear strength reduction).

Khan et al. (2014) conducted experimental testing on two extremely corrosion damaged shear-critical deep beams. The beams were taken out from a twenty-six years old corroded beam subjected to long-term chloride environment by cutting into two short-span beams. Corroding the stirrups did not change the failure modes of corroded deep beams. However, it resulted in a reduction in both shear strength and ductility of the corroded deep beams.

Wang et al. (2015) conducted an experimental investigation to investigate the influence of stirrup and inclined bar corrosion on the shear strength of corroded RC beams. They found that corrosion mass loss less than $10 \%$ in inclined bars and stirrups does not have a significant impact on the shear strength. However, higher corrosion rate results in damage in inclined bars and corroded stirrups, as well as degradation surrounding concrete section, which ultimately results in a significant reduction in the shear strength significantly, and changes the failure mode to a more brittle failure.

El-Sayed et al. (2016) conducted experimental testing on slender RC beams (flexural beams) with and without corroded shear reinforcement to investigate the shear behaviour of these corroded beams. They reported that about $7 \%$ mass loss in shear reinforcement results in about $10 \%$ reduction in shear strength of corroded $\mathrm{RC}$ beams. They also found that corrosion changes the shear failure mechanism of RC beams, which is in good agreement with the outcomes of the research carried out by Xia et al. (2011).

El-Sayed (2017) presented procedures for assessment of the shear capacity of RC beams with corroded shear reinforcement. They incorporated their procedure into the current shear design and assessment methods of RC beams, which can be used in the assessment of corroded beams. Their methodology has been validated against experimental results reported by Suffern et al. (2010), El-Sayed et al. (2016), and Khan et al. (2016). 
Fig. 2 shows the influence of corrosion on shear strength and ductility of the experimentally tested RC beams. In this figure, $V_{u, c o r r}$ is the shear strength capacity of the corroded RC beams and $V_{u, 0}$ denotes the corresponding value of uncorroded RC beams. Fig. 2 shows thatthe trend of residual shear strength and ductility of RC beams with increasing level of stirrups corrosion, is different with those of Fig 1. . Moreover, comparison of Fig. 2 and Fig. 1 shows that corrosion has a more significant adverse influence on flexural behaviour of corroded beams than shear (both strength and ductility).

\section{Experimental Investigation of Structural Performance of Corroded RC Columns}

The most common collapse mechanism of RC bridge piers, which is observed in the past earthquakes (e.g. Kobe 1998 and Chile 2010), is buckling of the vertical reinforcement together with crushing of core confined concrete and/or fracture of vertical bars. This is due to the lack of confining reinforcement in older RC columns. This problem is more critical in corrosion damaged bridge piers, where corrosion has a significant adverse influence on the stress-strain behaviour of reinforcing bars. Therefore, in this section a critical review of the experimental studies on nonlinear behaviour of corroded RC columns subject to pure axial, and combined axial and lateral loading is provided. It should be noted that despite the numerous experimental studies of corroded beams, there is very little experimental studies conducted on investigation of the effects of corrosion on nonlinear behaviour of RC columns.

\section{Adverse effect of corrosion on Axial Force capacity of RC Columns (AFRCC)}

Lee et al. (2000), and Bae et al (2005) conducted experimental studies on short columns to investigate the effectiveness of strengthening using CFRP sheets. They reported that corrosion has a significant impact on the axial load-displacement behaviour of RC columns in compression. The test results show that the corrosion significantly reduces the ductility and crushing strain of concrete in compression and to a lesser extent reduces the compressive strength. Lee et al. (2000) reported that the ductility ratio of the uncorroded specimen was 9.9 whereas the ductility of corroded column was 2.7 . They also took physical cross sections through the thickness of the unrepaired corroded column to explore the internal damage due to corrosion. The cross-section cuts showed that corrosion resulted in radial cracks in the cover concrete aligned with the vertical reinforcement. Moreover, they observed that a single crack had formed a continuous ring around the spiral reinforcement which resulted in complete delamination of the cover concrete. This is a very important observation that explains the significant influence of corrosion on the crushing strain of RC columns. 
It is recognised that the compressive behaviour of confined concrete depends on mechanical properties of transverse reinforcement including yield strength and fracture strain and volumetric ratio of tie reinforcement (Park et al. 1982; Mander et al. 1988a,b; Penelis and Kappos 1997). Since tie reinforcement is the outmost reinforcement to be exposed to chloride attack its corrosion starts prior to the corrosion initiation of the vertical reinforcing bars. Therefore, the volumetric ratio of confinement reinforcement, fracture strain and yield strength are reduced. Therefore, the tie reinforcement fractures much earlier than the uncorroded columns under compression.

Vu et al (2017) conducted a set of experimental testing to investigate the nonlinear behaviour of confined concrete with corroded transverse reinforcement (confinement reinforcement). They considered various corrosion-induced mass loos ratios of transverse reinforcement, arrangement and configuration of confinement reinforcement and cross-sectional shape of confined concrete. The experimental results showed that as mass loss ratio of confining reinforcement increases both capacity and ductility of the corrosion damaged confined concrete significantly decreases, and the post-peak softening branch of the stress-strain curye becomes much steeper. In other words,

Table 3 summarises the experimental studies carried out on corroded RC columns subjected to pure axial compression loading.

\section{Adverse effect of corrosion on nonlinear Flexural behaviour of Circular RC Columns (FCRCC)} rates of corrosion due to the splashing of de-icing salt from the adjacent road/or downfall of water carrying 
chloride ions from above (due to failure of expansion joints on the deck). This is very critical for bridges in seismic zones, where the lower region of bridge piers (or both ends in integral bridge piers) is exactly where plastic hinge is formed during earthquake excitation. Therefore, in all of the experimental testing of corroded bridge piers, researchers tested cantilever columns, and corrode either the entire column or only the lower region.

Aquino and Hawkins (2007) conducted a set of experimental tests on six RC columns. One column was used as the control uncorroded specimen, one column was used as a control corroded specimen without strengthening and the other four columns were strengthened using CPRP sheets. The columns were corroded using an accelerated corrosion procedure. In this experiment, only $1200 \mathrm{~mm}$ immediately above the base was corroded. In these columns a heavy accumulation of rust product on the surface of the concrete and a uniform staining of the corrosion along the length of longitudinal reinforcement is observed. Of these three columns (1, 3 and 5), Column 1 presented the most severe cracking and rust accumulation on the surface of concrete (Aquino and Hawkins, 2007). The observed damage in the uncorroded specimen was mainly due to the opening of a large crack at the connection between the column and the base due to slippage of the bars in the base. A few small flexural horizontal cracks were observed in the column along with major cracks running parallel to the longitudinal reinforcement, which appeared close to the maximum load and opened significantly when this load was attained. This is the typical failure mode of columns with insufficient lap splice lengths which does not allow the full strength and straining capacity of the reinforcing steel to be developed. However, the only corroded column without any strengthening tested in this study showed a different failure mode. Failure during the cyclic loading was due to buckling of the vertical reinforcement in compression. It was observed that most of the tie reinforcement (hoops) had fractured due to pitting corrosion and they had experienced a significant loss of crosssectional area during the corrosion process. The fracture of the tie reinforcement resulted in a significant loss of confinement and subsequently premature buckling of the corroded vertical reinforcement in compression (Aquino and Hawkins, 2007).

Ma et al. (2012) carried out a series of experimental testing on thirteen columns with varied corrosion levels and axial force ratios. They also used an accelerated corrosion procedure to corrode the test specimens. Each specimen consisted of a $260 \mathrm{~mm}$ diameter and $1000 \mathrm{~mm}$ long column cast into a $1300 \mathrm{~mm} \times 360 \mathrm{~mm} \times 400 \mathrm{~mm}$ base. The effective length of the columns was and the span to depth ratio were $820 \mathrm{~mm}$ and 3.15, respectively. The clear cover to the spirals was $30 \mathrm{~mm}$. Six $16 \mathrm{~mm}$ diameter reinforcing bars were used as vertical reinforcement and 
$8 \mathrm{~mm}$ diameter reinforcing bars at $100 \mathrm{~mm}$ spacing were used as the tie reinforcement (Ma et al. 2012). Eight out of thirteen columns had axial force ratios $\left(P / A_{g} f_{c}\right.$, where $P$ is the axial force, $A_{g}$ is the gross cross-sectional area of the columns, and $f_{c}$ is the compressive strength of concrete) between 0.15 and 0.4 and five of them had axial force ratios between 0.60 and 0.90 which are rather high compared to normal bridge columns. Therefore, only the results of eight columns with axial force ratios below 0.5 are discussed in this section. In the three control specimens (with different axial force ratios), the first flexural crack formed perpendicular to the column axis in the bottom of column where the plastic hinge region occurred. These cracks propagated and with the increasing lateral load diagonal cracks appeared. In the last cycle, the core concrete crushed indicating the failure of these specimens (Ma et al. 2012). The five corroded columns C9-15, C4-25, C9-25, C9-40 and C14-32, showed a flexural failure mechanism similar to the uncorroded specimens. However, the failure of these corroded specimens was very brittle. The crack spacing of corroded specimens at failure was greater than for the corresponding control specimens. As the displacement demand increased, cover concrete was spalled at the bottom of the column (plastic hinge region) which was then followed by severe buckling of the longitudinal bars and crushing of the core concrete. As expected the energy dissipation capacity and ductility of specimens decreased with increasing reinforcement corrosion and axial load ratio. Columns C0-25, C4-25 and C9-25 had the same axial load ratio, however a smaller hysteretic area was observed in severely corroded specimen C9-25. Specimen C9-15, C9-25 and C9-40 had almost the same corrosion level, but severe degradation in the hysteretic responses was observed with increasing the axial force ratio. Comparing the axial force and corrosion level, it was found that the corrosion level is the governing factor that affects the hysteretic behaviour. For example, specimen C14-32 which was subjected to slightly lower axial load than specimen C4-25, but which had more severe corrosion damage, showed very poor energy dissipation capacity and failed in a brittle manner. This was mainly due to the inelastic buckling of main bars (vertical reinforcement), which caused spalling concrete cover and crushing of core concrete.

Yuan et al. (2017) conducted experimental tests on eight circular RC columns with varied corrosion rates under combined repeated axial loading and cyclic lateral loading. In their experimental program column $\mathrm{C} 0$ was uncorroded, the three columns C5-L0, C5-L40 and C5-L60 were with target corrosion rate of 5\%, and four others, C10-L0, C10-L40, C10-L60 and CG10 were with target corrosion rate of 10\%. Using an electrochemical system, they implemented accelerated corrosion procedure to accelerate the corrosion rate of embedded reinforcing bars. Results showed that corrosion has a significant adverse impact on capacity of the columns. Moreover, they found 
that vertical axial loading has no significant impact on yield strength and ultimate capacity of the tested specimens. Based on their finite element analysis, the yield strength and ultimate displacement of corrosion damaged columns were declined by $35 \%$ and $34 \%$, respectively. A summary of the abovementioned experiments is presented in Table 4.

Fig. 3 shows the impact of corrosion on nonlinear flexural behaviour of all the experimentally tested circular RC columns in the literature. As it is shown in Fig. 3(a), there is no correlation the corrosion and residual ductility and strength of corroded beams using the available data $\left(R^{2}=-0.42\right)$. This is because there are only 11 data points

\section{Adverse effect of corrosion on nonlinear Flexural behaviour of Rectangular RC Columns (FRRCC)}

Lee et al. (2003) conducted experimental testing on six rectangular RC columns with $300 \mathrm{~mm} \times 300 \mathrm{~mm}$ in cross section and $1100 \mathrm{~mm}$ in height. They also used accelerated corrosion procedure to produce various corrosion levels. The columns tested under simultaneous axial and lateral cyclic loading. They found that corrosion results in a severe decrease in mechanical properties of reinforcing bars and spalling of concrete cover, which caused a significant reduction in confinement of core concrete. In their experiment, the failure of uncorroded specimen initiated by bond failure and slippage of vertical bars. However, corrosion changed this failure mode to buckling of vertical reinforcement and fracture of hoops (confinement reinforcement).

Meda et al. (2014) conducted experimental testing on corroded and uncorroded rectangular columns under cyclic loading. They used accelerated corrosion procedure to corrode the columns. The columns were tested under axial $(400 \mathrm{kN})$ and lateral cyclic loading with about $20 \%$ corrosion mass loss of vertical reinforcements. It should be noted that Meda et al. (2014), just corroded the vertical reinforcing bars, and the transverse reinforcements were 
protected from corrosion. They reported that corrosion has a significant impact on the nonlinear response of rectangular RC columns subjected to cyclic loading. They observed corrosion results in about $30 \%$ reduction in the ultimate strength and about 50\% reduction in the ductility, as well as significant cyclic degradation (loss of stiffness) in the last cycles.

Guo et al. (2015b) conducted a set of experimental testing on corroded and uncorroded cantilever rectangular RC bridge piers. The test specimens were corroded using accelerated corrosion procedure, and tested under combined Rafiq M.I 2013). axial and lateral cyclic loading. They found that corrosion mass loss greater than $10 \%$ results in severe degradation in nonlinear cyclic behaviour of RC bridge piers. They reported that heavily corroded column with average mass loss of $15.24 \%$ shows the smallest hysteretic responses, greatest cyclic degradation of stiffness and strength, and subsequently a significant reduction in ductility and energy dissipation capacity.

All the previous experimental studies on flexural behaviour of corroded rectangular RC columns are summarised in Table 5. Fig. 4 summarises the influence of corrosion on flexural behaviour of rectangular RC columns. Comparing Fig. 4(a) with Fig. 4(b), ductility reduction of corroded rectangular columns is slightly more than their flexural capacity loss. The other interesting finding is that the fitted line equation for flexural strength loss of rectangular RC columns (Fig. 4(a)) is same to that of rectangular RC beams (Fig. 1(a)).

\section{Numerical Modelling of Corroded RC Components}

\section{Modelling nonlinear flexural behaviour}

In the recent few years, a significant number of researchers have employed analytical and nonlinear finite element analysis approaches (Coronelli and Gambarova 2004, El Maaddawy et al. 2005b, Kallias 2011, for structural performance evaluation of corroded RC components. Azam (2010) and Alaskar (2013) have used modified compression field theory (MCFT) to estimate the shear strength of uncorroded and corroded RC beams. More recently, Di Carlo et al. (2017a,b) have employed 3D continuum finite element modelling approaches for nonlinear structural and seismic performance assessment of corroded RC bridge piers subject to cyclic loading. Considering its capability in nonlinear bond-slip modelling, the 3D finite element modelling approach is widely used in the literature to develop the bond strength deterioration models (Lundgren et al. (2012), Kallias A.M and Rafiq M.I 2013)

All of these numerical models have been validated against some benchmark experimental test data. 
414 Although all the aforementioned numerical models can simulate the nonlinear behaviour of RC components with 415 relatively good accuracy, they are computationally very expensive. Therefore, it is not possible to easily 416 implement these models in nonlinear dynamic analyses and seismic fragility assessment of bridge systems. 417 Accordingly, researchers in earthquake engineering community have employed force-based fibre beam-column 418 element (Spacone et al. 1996a and 1996b, Taucer et al. 1991) for seismic fragility assessment of corroded RC bridges. A force-based fibre beam-column element is a line element in which the moment-curvature response at integration points is determined from the assigned fibre sections for each integration point. Currently, forcedbased fibre elements are the most advanced 1D models available in the literature for nonlinear analysis of RC components. In the force-based elements, moment is considered to be distributed along the entire length of the column. The curvatures at each section (integration point) are accordingly estimated for the given moment at that section. Weighting the integration of the sections' response, finally, the column response is obtained. (Taucer et al. 1991). Using a fibre section technique, the cross section of the member is discretised into several concrete and steel fibres. The material nonlinearity is considered through uniaxial constitutive material models for reinforcing steel and concrete (confined and unconfined concrete cover), and hence, the accuracy of the model is highly dependent on the accuracy of the material models. Therefore, several researchers have put significant effort to implement corrosion damaged material models in nonlinear fibre beam-column elements. Kashani et al. (2015b) proposed a phenomenological hysteretic material model for uncorroded and corroded reinforcing bars. This model simulates the influence of corrosion on low-cycle fatigue and inelastic buckling behaviour of reinforcing steel bars. Rao et al. (2016a) proposed a simplified nonlinear analytical model to simulate corrosioninduced degradation of RC bridge pier. The main focus of this models is on average cross-sectional area reduction of reinforcing bars due to corrosion and other deteriorating mechanisms are disregarded.

Dizaj et al. (2018a) developed a modelling technique using force-based fibre beam-column element for nonlinear seismic performance evaluation of corroded RC bridge piers, which is currently the most advanced model available in the literature. This model is validated against a benchmark experimental testing conducted by Meda et al. (2014), then implemented in vulnerability assessment of corrosion damaged RC frames (Dizaj et al., 2018b).

Although fibre beam-column element models are very efficient in simulation nonlinear flexural response of RC components, they do not account for nonlinear shear deformation and axial-shear-flexure interaction. Therefore, in shear critical RC components, fibre beam-column elements are not very accurate. Some researchers have used 
uncoupled nonlinear shear springs to account for shear deformation in uncorroded RC components, but these

springs do not account for axial-shear-flexure interaction (Jeon et al., 2015). However, there has not been any significant research conducted on modelling axial-shear-flexure interaction in corroded RC components. This is an important area for future studies (further discussion is available in section 5 of this paper).

\section{Comparison of the state-of-the-art numerical models with available experimental data}

As discussed in previous section, the nonlinear moment-curvature response of RC sections (accounting for axialflexure interaction) is extremely important for structural assessment of corroded RC bridge piers and beams. Furthermore, moment-curvature response of cross section is the basis of nonlinear fibre beam-column element model implementation for seismic performance assessment of uncorroded and corroded RC bridges. In this section, a comparison has been made between the predicted residual bending moment capacity of corroded beams and columns using the state-of-the-art models in the literature and the available experimental results.

The detailed derivation of theoretical axial force-moment-curvature relationship of corroded RC sections is discussed in Kashani et al. (2017). The main assumptions in this method are: (i) plane sections remain plane and (ii) shear stress/deformation in the beam is small, and hence, there is no shear-flexure (Euler-Bernoulli beam theory). This technique accounts for inelastic buckling of the compression reinforcing bars (Kashani, 2014). The slenderness ratio, $L_{e f f} / D$, used in the buckling model was taken as the ratio of effective buckling length ( $\left.L_{e f f}\right)$ to diameter of vertical reinforcement $(D)$. In this study, the $L_{\text {eff }}$ is taken from the experimental results. In the absence of experimental data, the procedure developed by Dhakal and Maekawa (2002) can be used to calculate the $L_{\text {eff. }}$. The constitutive material models that are used here are the ones that originally developed by Kashani (2014), and later validated by Dizaj et al. (2018a). These models account for the adverse impact of corrosion on nonlinear stress-strain behaviour of reinforcing bars (strength and ductility), inelastic buckling of longitudinal reinforcement in compression (vertical bars in columns), cracked concrete cover, and core confined concrete (due to corrosion of confinement reinforcement). The detailed discussion of the material models is available in (Kashani et al., 2016).

Using the numerical modelling technique developed by Kashani et al. (2017), the bending moment capacity of all the corroded and uncorroded rectangular columns (with various axial force) and flexural beams are computed and plotted against their corresponding experimental values (reported in Tables 1 and 5) in Fig. 5. In this figure, $M_{u, \text { comp }}$ is the computational ultimate moment of the tested specimens and $M_{u, \text { xxp }}$ is that of their corresponding 
experimental values. As it is shown in Fig. 5, there is a good correlation between the predicted and experimental values of bending moment capacity. This confirms that the developed numerical model is able to precisely predict the residual capacity of corroded RC components. A quantitative comparison between the computed values and experimental data have been prepared in a set of tables and attached as downloadable supplementary material (Comp Vs Exp.xlsx).

\section{Outstanding Issues and Needs for Future Research}

There is a large amount of experimental data available in the literature on large-scale testing of corroded RC beams in flexure and/or shear under monotonic and cyclic static loading. In comparison to corroded RC beams, there is very little experimental data available in the literature on large-scale testing of corroded RC columns (rectangular and circular) under axial and static lateral loading (monotonic and cyclic). All the previous experimental testing of corroded RC columns has been conducted on flexural govern columns, and there has been no experimental testing on shear critical columns. In general, there is a need for further experimental testing on RC columns with different geometry, reinforcing details, axial force ratios, and shear span to depth ratio. In terms of modelling, there is a large number of numerical models in the literature using 2D and 3D continuum finite element and nonlinear fibre element technique using beam-column models. The existing models can predict the residual capacity and simulate the nonlinear behaviour of RC elements under flexural loading very well (including modelling axial-flexure interaction). However, modelling axial-shear-flexure interaction is a major challenge in fibre element technique, as the nonlinear beam-columns elements employ Euler-Bernoulli beam theory and do not account for axial-shear-flexure interaction. This is in addition to the significant paucity in the literature on the impact of corrosion on shear critical columns. Moreover, there is only one experimental testing available in the literature on corroded RC columns under dynamic earthquake loading (Yuan et al., 2018). There is a need for some benchmark shaking table experimental tests on corroded RC columns with different reinforcement details and ground motion types. Furthermore, recent advances in X-Ray Computing Tomography (CT) scanning facilities, allow researchers to scan corroded RC elements using X-Ray CT scanner prior to structural testing (Lim et al., 2017). The advancement in CT scan technology and computing power allows more sophisticated 3D multi-scale multi-physics nonlinear finite element modelling of corroded RC elements (Michel et al., 2015). The advantage of multi-scale multi-physics is that researchers can model the whole process of corrosion induced progressive damage in structural integrity as well as residual capacity of corroded RC elements. 
Another advantage of multi-scale modelling is that multiple failure modes can be automatically captured (e.g. axial-shear-flexure). However, there is a need for significant experimental and computational research to validate and calibrate the new multi-scale multi-physics models. However, these models are computationally very expensive, and therefore, the major challenge in future will be implementing these models in the analysis of whole bridge structures under various loading scenarios (traffic, trains, earthquakes etc.).

\section{Conclusions}

An extensive review of all the experimental research on corroded RC components including (i) beams in flexure,

(ii) beams in shear, (iii) columns under pure axial compressive loading, (iv) circular columns in flexure, and (v) rectangular columns in flexure is conducted. Furthermore, a crucial review of the current state-of-the-art numerical models in the literature is conducted, and an exemplary comparison has been made between these models and experimental testing of corroded RC beams in flexure. The main findings of this state-of-the-art review paper can be summarised as follows:

(1) Regression analyses of all the experimental studies on corroded RC beams show that both the flexural strength and ductility loss follow a similar linear trend, with ductility loss being more critical than strength loss.

(2) Corrosion has less adverse impact on residual shear strength of corroded RC beams in comparison with residual flexural strength. Moreover, the trend of shear strength loss of corrosion damaged RC beams with increasing level of corrosion is different with that of flexural behaviour.

(3) As corrosion level increases, the ductility and compressive strength of confined concrete decreases. This results in a significant reduction in axial compressive capacity of RC columns in seismic regions.

(4) Experimental results show that flexural strength reduction of corroded rectangular RC columns is generally more than corroded circular RC columns. However, the number of available experimental tests in the literature is not sufficient to draw a solid conclusion, and therefore, there is need for further research in the future.

(5) While the flexural behaviour of rectangular corroded RC columns follows a linear trend, there is not any solid evidence to show this trend for circular columns. This confirms that there is a need for further experimental researches on corrosion damaged circular columns. 
(6) Exemplary comparisons between the computational residual capacity of corroded RC beams and columns with their corresponding experimental values, confirms that the currently available models in the literature can accurately anticipate the residual capacity of corrosion damaged RC beams and columns in flexure.

\section{References}

Alaskar, A. (2013). "Shear Behaviour of Slender RC Beams with Corroded Web Reinforcement”. Master thesis, University of Waterloo, Ontario, Canada.

Afsar Dizaj, E., Madandoust, R., Kashani, M. M. (2018a). "Exploring the impact of chloride-induced corrosion on seismic damage limit states and residual capacity $\rho$ of reinforced concrete structures"., Struct Infrastruct Eng., 14(6):714-29.

Afsar Dizaj, E., Madandoust, R., Kashani, M. M. (2018b). "Probabilistic seismic vulnerability analysis of corroded reinforced concrete frames including spatial variability of pitting corrosion"., Soil Dynamics and Earthquake Engineering., 114: 97-112.

Akiyama, M., Frangopol, D. M. (2013). "Long-term seismic performance of RC structures in an aggressive environment: emphasis on bridge piers." Struct Infrastruct E., 10 (7): 865-879.

Akiyama, M., Frangopol, D. M., Matsuzaki, H. (2011). "Life-cycle reliability of RC bridge piers under seismic and airborne chloride hazards.” Earthquake Eng and Struct Dyn., 40: 1671-1687.

Alexopoulos, N. D., Apostolopoulos, C. A., Papadopoulos, M. P., Pantelakis, S.G. (2007). "Mechanical Performance of BStIV Grade Steel Bars with Regard to the Long-term Material Degradation Due to Corrosion Damage.” Constr Build Mater., 21(6): 1362-1369.

Alipour, A., Shafei, B. and Shinozuka, M. (2011). "Performance evaluation of deteriorating highway bridges located in high seismic areas.” J Bridge Eng., 6 (5): 597-611.

Almusallam, A.A. (2001). "Effect of degree of corrosion on the properties of reinforcing steel bars." Const and Build Mat., 15(8): 361-368.

Al-Saidy A. H., Saadatmanesh, H., El-Gamal, S., Al-Jabri K. S., Waris, B. M. (2016). "Structural behavior of corroded RC beams with/without stirrups repaired with CFRP sheets." Materials and Structures 49 (9): 3733 3747.

American Society of Civil Engineers. (2013). Report Card for America's Infrastructure. Retrieved from https://www.infrastructurereportcard.org/a/\#p/bridges 
Apostolopoulos, C. A. (2009). "The influence of corrosion and cross-section diameter on the mechanical

554

555

556

557 properties of B500c steel.”J Mater Eng Perfor., 18 (2): 190-195.

Apostolopoulos, C. A., Koutsoukos, P. G. (2008). "Study of the corrosion of reinforcement in concrete elements used for the repair of monuments." Constr Build Mater., 22 (7): 1583-1593.

Apostolopoulos, C. A., Michalopoulos, D. (2007). "Corrosion of reinforcing steel and low cycle fatigue behaviour." Mater Corr., 58 (6): 438-446.

Apostolopoulos, C. A., Papadakis, V. G. (2008). "Consequences of steel corrosion on the ductility properties of reinforcement bar.” Constr Build Mater., 22(12): 2316-2324.

Apostolopoulos, C. A., Papadopoulos, M. P. (2007). "Tensile and low cycle fatigue behavior of corroded reinforcing steel bars S400.” Constr Build Mater., 21(4): 855-864.

Apostolopoulos, C. A., Papadopoulos, M. P., Pantelakis, S. G. (2006). “Tensile behavior of corroded reinforcing steel bars BSt 500s." Construct and Build Mater., 20(9): 782-789.

Apostolopoulos, C. A., Pasialis, V. P. (2008). "Use of quality indices in comparison of corroded technical steel bars B500c and S500s on their mechanical performance basis." Constr Build Mater., 22 (12): 2325-2334.

Aquino, W. (2002). "Long-term performance of seismically rehabilitated corrosion-damaged columns." PhD Thesis, University of Illinois at Urbana Champaign.

Aquino, W., Hawkins, N. M. (2007). "Seismic Retrofitting of Corroded Reinforced Concrete Columns Using Carbon Composites." ACI Structural Journal., 104(3): 348-356.

Azad, A. K., Ahmad, S., Azher, S. (2007). "Residual strength of corrosion-damage reinforced concrete beams." ACI Struct J., 104 (1): 40-47.

Azad, A. K., Ahmad, S., Al-gohi, B. H. A. (2010). "Flexural strength of corroded reinforced concrete beams.” Magazine of Concrete Research., 62 (6): 405-414.

Azam, R. (2010). "Behaviour of shear critical RC beams with corroded longitudinal steel reinforcement," MASc Thesis, University of Waterloo, Waterloo, Ontario, Canada.

Bae, S.W., Belarbi, A., and Myers, J.J. (2005). "Performance of Corrosion-Damaged RC Columns Repaired by CFRP Sheets.” ACI, Special Publication; 230: 1447-1464.

Belarbi, A. 1., Sang-Wook, B. (2007). “An experimental study on the effect of environmental exposures and corrosion on RC columns with FRP composite jackets." Compos Part B: Eng., 38 (5): 674-684. 
Berto, L., Vitaliani, R., Saetta, A., Simioni, P. (2009). "Seismic assessment of existing RC structures affected by

582

583

584

585

586

587

588

589

590

591

592

593

594

595

596

597

598

599

600

601

602

603

604

605

606

607

608

degradation phenomena." Struct Saf., 31(4): 284-297.

Biondini, F., Camnasio, E., Palermo, A. (2014). "Lifetime seismic performance of concrete bridges exposed to corrosion.” Struct Infrastruct E., 10(7): 880-900.

Bousias, S. N., Triantafillou, T. C., Fardis, M. N., Spathis, L. (2004). "Fiber-reinforced polymer retrofitting of rectangular reinforced concrete columns with or without corrosion.” ACI sruct J., 101 (4).

Broomfield, J. P. (2007). Corrosion of steel in concrete: understanding, investigation and repair. 2. Taylor and Francis.

Cairns, J., Du, Y., Law, D. (2008). "Structural performance of corrosion-damaged concrete beams." Mag Concrete Res., 60 (5): 359-370.

Cairns, J., Plizzari, G. A., Du, Y. G., Law, D. W., Chiara, F. (2005). "Mechanical properties of corrosiondamaged reinforcement.” ACI Mat J., 102 (4): 256-264.

Castel, A., Francois, R., Arliguie, G. (2000). "Mechanical behaviour of corroded reinforced concrete beams-Part 1: experimental study of corroded beams." Materials and Structures., 33(9):539-544.

Chiu, C. K., Tu, F. J., and Hsiao, F. P. (2015). "Lifetime seismic performance assessment for chloride-corroded reinforced concrete buildings.” Structure and Infrastructure Engineering., 11(3): 345-362.

Choe, D., Gardoni, P., Rosowsky, D., and Haukaas, T. (2008). "Probabilistic capacity models and seismic fragility estimates for RC columns subject to corrosion.” Reliab Eng Syst Safe., 93(3): 383-393.

Choe, D., Gardoni, P., Rosowsky, D., Haukaas, T. (2009). "Seismic fragility estimates for reinforced concrete bridges subject to corrosion." Struct Saf., 31(4): 275-283.

Chung, L., Husam, N., Perumalsamy, B. (2008). "Flexural behavior of concrete slabs with corroded bars.

Cement \& Concrete Composites" Cement Concrete Composites., (30): 184-193.

Coronelli, D., Gámbarova, P. (2004). "Structural assessment of corroded reinforced concrete beams: modelling guidelines." J Struct Eng., 130 (8): 1214-1224.

Cui, F., Zhang, H., Ghosn, M., \& Xu, Y. (2018). "Seismic fragility analysis of deteriorating RC bridge substructures subject to marine chloride-induced corrosion." Engineering Structures, 155, 61-72.

Dhakal, R. P., Maekawa, K. (2002). “Reinforcement stability and fracture of cover concrete in RC members.” J of Struct Eng., 128 (10): 1253-1262. 
Di Carlo, F., Meda, A., \& Rinaldi, Z. (2017a). "Numerical evaluation of the corrosion influence on the cyclic

610 behaviour of RC columns.”, Engineering Structures., 153, 264-278.

611 Di Carlo, F., Meda, A., \& Rinaldi, Z. (2017b). "Numerical cyclic behaviour of un-corroded and corroded RC 612 columns reinforced with HPFRC jacket.”, Composite Structures., 163, 432-443.

613 Du, Y., Clark, L. A., Chan, A. H. C. (2007). "Impact of reinforcement corrosion on ductile behaviour of 614 reinforced concrete beams.” ACI Struct J., 104 (3): 285-293.

615 Du, Y. G., Clark, L. A., Chan, A. H. C. (2005a). "Effect of corrosion on ductility of reinforcing bars." Magazine 616 of Conc Res., 57 (7): 407-419.

617 Du, Y. G., Clark, L. A., Chan, A. H. C. (2005b). "Residual capacity of corroded reinforcing bars." Magazine of $618 \quad$ Conc Res., 57 (3): 135-147.

619 El Maaddawy, T., Soudki, K., Topper, T. (2005a). "Analytical model to predict nonlinear flexural behaviour of 620 corroded reinforced concrete beams.” ACI Struct J., 102 (4): 550-559.

621 El Maaddawy, T., Soudki, K., Topper, T. (2005b). "Long-Term Performance of Corrosion-Damaged 622 Reinforced Concrete Beams.” ACI Struct J., 102 (5): 649-656.

623 El-Sayed, .A. K. (2017). "Shear capacity assessment of reinforced concrete beams with corroded 624 stirrups." Construction and Building Material., 134: 176-184.

625 El-Sayed, .A. K., Hussain, R . R., Shuraim, A. (2016). "Influence of Stirrup Corrosion on Shear Strength of 626 Reinforced Concrete Slender Beams.” ACI Structural Journal., 113(6): 1223-1232.

627 Fernandez, I., Bairan, J. M., \& Mari, A. R. (2015). Corrosion effects on the mechanical properties of reinforcing 628 steel bars. Fatigue and $\sigma-\varepsilon$ behàvior, Construction and Building Materials., 101, 772-783.

629 Ghosh, J., Padgett, J. (2010). "Aging considerations in the development of time-dependent seismic fragility 630 curves.” J Struct Eng., 136 (12): 1497-1511.

631 Ghosh, J., Sood, P. (2016). "Consideration of Time-Evolving Capacity Distributions and Improved Degradation 632 Models for Seismic Fragility Assessment of Aging Highway Bridges.” Reliability Engineering \& System Safet., $633 \quad 154: 197-218$.

634 Guo, A., Yuan, W., Lan, Ch, Guan, X., Li, H. (2015a). "Time-dependent seismic demand and fragility of 635 deteriorating bridges for their residual service life.” Bulletin of Earthquake Engineering., 13(8): 2389-2409 
636 Guo, A., Li, H., Ba, X., Guan, X., Li, H. (2015b). "Experimental investigation on the cyclic performance of 637 reinforced concrete piers with chloride-induced corrosion in marine environment. " Engineering Structures., 105: $638 \quad 1-11$.

639 Higgins, Ch., Farrow, W. (2006). "Tests of Reinforced Concrete Beams with CorrosionDamaged Stirrups.” 640 ACI Structural Journal., 103(1): 133-141.

641 Jeon, J. S., DesRoches, R., Lowes, L. N., Brilakis, I. (2015). "Framework of aftershock fragility assessment-case 642 studies: older California reinforced concrete building frames." Earthquake Engineering and Structural 643 Dynamics., 44(15):2617-2636.

644 Kallias, A. N. (2011). "Advanced probabilistic resistance assessment of corroding RC beams.” PhD Thesis, 645 University of Surrey.

646 Kashani., M. M. (2014). "Seismic Performance of Corroded RC Bridge Piers: Development of a Multi647 Mechanical Nonlinear Fibre Beam-Column Model.” PhD Thesis, Bristol: University of Bristol.

648 Kashani, M. M., Alagheband, P., Khan, R., \& Davis, S. (2015a). Impact of corrosion on low-cycle fatigue 649 degradation of reinforcing bars with the effect of inelastic buckling. International Journal of Fatigue, 77, 174650185.

651 Kashani, M. M., Lowes, L. N., Crewe, A. J., Alexander,N. A. (2015b). "Phenomenological hysteretic model for 652 corroded reinforcing bars including inelastic buckling and low-cycle fatigue degradation." Comput Struct., 156: $653 \quad 58-71$.

654 Kashani, M. M., Lowes, L. N, Crewe, A. J., \& Alexander, N. A. (2016). "Nonlinear fibre element modelling of 655 RC bridge piers considering inelastic buckling of reinforcement.” Engineering Structures., 116, 163-177.

656 Kashani, M. M., Crewe, A. J., \& Alexander, N. A. (2013a). "Nonlinear cyclic response of corrosion-damaged 657 reinforcing bars with the effect of buckling." Construction and Building Materials., 41, 388-400.

658 Kashani, M. M., Crewe, A. J., \& Alexander, N. A. (2013b). "Nonlinear stress- strain behaviour of corrosion659 damaged reinforcing bars including inelastic buckling.” Engineering Structures., 48, 417-429.

660 Kashani, M. M., Crewe A. J., Alexander, N. A. (2017). "Structural capacity assessment of corroded RC bridge 661 piers.” Proceedings of the Institution of Civil Engineers-Bridge Engineering., 170(1): 28-41.

662 Kallias, A.N., Rafiq, M.I. (2013). "Performance assessment of corroding RC beams using response surface 663 methodology”., Engineering Structures., 49: 671-685. 
664 Khan, I., Francois, R., Catel, A. (2014). "Experimental and analytical study of corroded shear-critical

665 reinforced concrete beams.” Materials and Structures, 47:1467-1481.

666 Lee, C., Bonacci, J. F., Thomas, M. D., Maalej, M., Khajehpour, S., Hearn, N., Sheikh, S. (2000). “Accelerated 667 corrosion and repair of reinforced concrete columns using carbon fibre reinforced polymer sheets." Can J Civil $668 \quad$ Eng., 27 (5): 941-948.

669 Lee, H., Kage, T., Noguchi, T., Tomosawa, F. (2003). "An experimental study on the retrofitting effects of 670 reinforced concrete columns damaged by rebar corrosion strengthened with carbon fibre sheets." Cement 671 Concrete Res., 33: 536-570.

672 Lee, H. S., Cho, Y. S. (2009). "Evaluation of the mechanical properties of steel reinforcement embedded in 673 concrete specimen as a function of the degree of reinforcement corrosion." Int J Fracture., 157 (1-2): 81-88.

674 Li, X., Liang, Y.-S., Zhao, Z.-H., \& Lv, H.-L. (2015). Low-cycle fatigue behavior of corroded and CFRP675 wrapped reinforced concrete columns. Construction and Building Materials, 101, 902-917.

Liu, X., Jiang, H., He, L. (2017). "Experimental investigation on seismic performance of corroded reinforced concrete moment-resisting frames.” Engineering Structures., 153: 639-652.

Li, D., Wei, R., Xing, F., Sui, L., Zhou, Y., Wang, W. (2018). "Influence of Non-uniform corrosion of steel bars on the seismic behaviour of reinforced concrete columns". Construction and Building Materials., 167: 2032.

Li, J., Gong, J., Wang, L. (2009). "Seismic behavior of corrosion-damaged reinforced concrete columns strengthened using combined carbon fiber-reinforced polymer and steel jacket”. Construction and Building Materials., 23: 2653-2663.

Lim, S., Akiyama, M., Frangopol, D. M., \& Jiang, H. (2017). "Experimental investigation of the spatial variability of the steel weight loss and corrosion cracking of reinforced concrete members: novel X-ray and digital image processing techniques.”, Structure and Infrastructure Engineering., 13(1), 118-134. behaviour of corroded ribbed reinforcement"., Structure and Infra Structure Engineering., 8(2): 157-169. Ma, Y., Che, Y., Gong, J. (2012). "Behavior of corrosion damaged circular reinforced concrete columns."

690 Construction and Building Materials., 29: 548-556.

691 Malumbela, G., Moyo, P., Alexander, M. G. (2009). "Behaviour of RC beams corroded under sustained service 692 loads.”, Construction \& Building Materials., 23: 3346-3351. 
693

694

695

696

697

698

699

700

701

702

703

704

705

706

707

Mander, J. B., Priestley, M. J. N., Park, R.. (1988a). “Observed stress-strain behavior of confined concrete.” J Struct Eng., 114 (8): 1827-1849.

Mander, J. B., Priestley, M. J. N., Park, R. (1988b). “Theoretical stress-strain model for confined concrete.” J Struct Eng., 114 (8): 1804-1825.

Mangat, P. S., and Elgarf, M. S. (1999). "Flexural Strength of Concrete Beams with Corroding Reinforcement.” ACI Structural Journal., 96(1): 149-159.

McKenna, F. (2011). “OpenSees: a framework for earthquake engineering simulation.” Computing in Science \& Engineering., 13(4): 58-66.

Meda, A., Mostosi, S., Rinaldi, Z., \& Riva, P. (2014). Experimental evaluation of the corrosion influence on the cyclic behaviour of RC columns. Engineering Structures., 76: 112-123.

Michel, A., Geiker, M. R., Stang, H., \& Lepech, M. (2015). "Multi-Physics and Multi-Scale Deterioration Modelling of Reinforced Concrete Part I: Coupling Transport and Corrosion At the Material Scale.” In 2015 Symposium of the Federation Internationale du Beton (fib). Copehnagen, Denmark: fib.

Ni Choine, M., Kashani, M. M., Lowes, L. N., O'Connor, A., Crewe, A. J., Alexander, N. A., Padgett, J. E. (2016). "Nonlinear dynamic analysis and seismic fragility assessment of a corrosion damaged integral bridge." International Journal of Structural Integrity., 7 (2): 227-239.

Ou, Y., Chen, H. (2014). "Cyclic Behavior of Reinforced Concrete Beams with Corroded Transverse Steel Reinforcement." Journal of Structural Engineering., 140(9): 04014050.

Ou, Y. C., Fan, H. D., Nguyen, N. D. (2013). "Long-term seismic performance of reinforced concrete bridges under steel reinforcement corrosion due to chloride attack.” Earthq Eng Struct D., 42 (14): 2113-2127.

Ou, Y., Tsai, L., Chen, H. (2011). "Cyclic performance of large-scale corroded reinforced concrete beams." Earthquake Eng and Struct Dyn., 41(4): 592-603.

Palsson, R., Mirza, M. S. (2002). "Mechanical response of corroded steel reinforcement of abandoned concrete bridge.” ACI Struct J., 99 (2): 157-162.

Pantazopoulou, S. J., Bonacci, J. F., Sheikh, S. T., Thomas, M. D. A., Hearn, N. A. (2001). "Repair of corrosiondamaged columns with FRP wraps.” J compos constr., 5 (1): 3-11.

Papadopoulos, M. P., Apostolopoulos, C. A., Alexopoulos, N. D., Pantelakis, S. G. (2007). "Effect of salt spray corrosion exposure on the mechanical performance of different technical class reinforcing steel bars." Mater Des., 28 (8): $2318-2328$. 
Park, R., Priestley, N., Gill, W. (1982). "Ductility of square-confined concrete columns.” J Struct Div., 108 (4): 929-950.

Penelis, G., Kappos, A. (1997). "Earthquake resistance concrete structures.” London: E \& FN Spon.

Rao, A. S., Lepech, M. D., Kiremidjian, A. S., \& Sun, X.-Y. (2016a). "Simplified structural deterioration model for reinforced concrete bridge piers under cyclic loading." Structure and Infrastructure Engineering., 13(1): 5566.

Rao, A. S., Lepech, M. D., Kiremidjian, A. (2016b). "Development of time-dependent fragility functions for deteriorating reinforced concrete bridge piers.” Structure and Infrastructure Engineering, 13(1): 67-83.

Razak, H. A., Choi, F. C. (2001). "The effect of corrosion on the natural frequency and modal damping of reinforced concrete beams.” Eng Struct 23 (9): 1126-1133.

Rodriguez, J., Ortega, L. M., Casal, J., Diez, J. (1996). “Corrosion of reinforcement and service life of concrete structures." Sweden: Seventh International Conference on Durability of Building Materials and Components, E\&FN Spon Publisher.

Rodriguez, J., Ortega, L. M., Aragoncillo, J., Izquierdo, D., Andrade, C. (2005). "Methodology for the structural assessment of concrete affected by reinforcement corrosion.” ACI Struct J SP., 229: 305-318.

Rodriguez, J., Ortega, L. M., Casal, J. (1997). "Load carrying capacity of concrete structures with corroded reinforcement." Constr Build Mater., 11 (4): 239-248.f

Simon, J., Brac, J. M., Gardoni, P. (2010). "Seismic Response and Fragility of Deteriorated Reinforced Concrete Bridges.” Journal of Structural Engineering., 136(10): 1273-1281.

Spacone, E., Filippou, F. C., Taucer, F. F. (1996a). "Fibre beam-column model for non-linear analysis of R/C frames: part I: formulation.” Earthq Eng Struct D., 25: 711-725.

Spacone, E., Filippou, F. C., Taucer, F. F. (1996b). "Fibre beam-column model for non-linear analysis of R/C frames: part II: applications.” Earthq Eng Struct D., 25: 727-742.

Stewart M.G. (2004). "Spatial variability of pitting corrosion and its influence on structural fragility and reliability of RC beams in flexure.” Structural Safety., 2004; 26(4): 453-470.

Suffern, Ch., El-Sayed, A., Soudki, Kh. (2010). "Shear strength of disturbed regions with corroded stirrups in reinforced concrete beams." Can. J. Civ. Eng. 37: 1045-1056.

Tastani, S. P., Pantazopoulou, S. J. (2004). "Experimental evaluation of FRP jackets in upgrading RC corroded columns with substandard detailing.” Eng Struct., 26 (6): 817-829. 
Taucer, F., Spacone, E., Filippou, F. C. (1991) . “A fiber beam-column element for seismic response analysis of reinforced concrete structures.” Berkeley: EERC College of Engineering, University of California.

Torres-Acosta, A. A., Navarro-Gutierrez, S., Teran-Guill'en, J. (2006). "Residual flexure capacity of corrode reinforced concrete beams.” Engineering Structures., (29): 1145-1152.

Transportation Research Board. (1991). "Highway deicing: Comparing salt and calcium magnesium acetate, special report 235.” Washington, DC: National Research Council.

Vidal, T., Castel, A., Francois, R. (2004). "Analysing crack width to predict corrosion in reinforced concrete." Cement Concrete Res., 34(1): 165-174.

Vu, N. S., Yu, B., \& Li, B. (2016). "Prediction of strength and drift capacity of corroded reinforced concrete columns." Construction and Building Materials., 115, 304-318.

Vu, N. S., Yu, B., \& Li, B. (2017). "Stress-strain model for confined concrete with corroded transverse reinforcement.” Engineering Structures 151: 472-487.

Wallbank., E. J. (1989). “The performance of concrete in bridges: A survey of 200 highway bridges.” London: H.M.S.O.

Wang, L., Zhang, X., Ma, Y., Liu, Y. (2015). "Effects of stirrup and inclined bar corrosion on shear behaviour of RC beams." Construction and Building Materials., 98: 537-546.

Xia, J., Jin, W., Li, L. (2011). "Shear performance of reinforced concrete beams with corroded stirrups in chloride environment." Corrosion Science., 53: 1794-1805.

Yang, Sh., Song, X., Jia, H., Chen, X., Liu, X. (2016). “Experimental research on hysteretic behaviors of corroded reinforced concrete columns with different maximum amounts of corrosion of rebar". Construction and Building Materials., 121: 319-327.

Ye, Z., Zhang, W., Gu, X. (2018). "Deterioration of shear behavior of corroded reinforced concrete beams"., Engineering Structures., 168: 708-720.

Yuan, Z., Fang, C., Parsaeimaram, M., Yang, S. (2017). “Cyclic Behavior of Corroded Reinforced Concrete Bridge Piers"., Journal of Bridge Engineering., 22(7):1-21.

Yu, L., Francois, R., Dang, V. H., L'Hostis, V., Gangne, R. (2015). "Structural performance of RC beams damaged by natural corrosion under sustained loading in a chlorine environment." Engineering Structures., 96: $30-40$. 

Acoustic Emission," J. Engineering Mechanics, ASCE, 126(3), 189-194.

781

Yuan, W., Guo, A., Yuan, W., Li, H. (2018). "Shaking table tests of coastal bridge piers with different levels of corrosion damage caused by chloride penetration.”, Construction and Building Material., 173: 160-171.

Zhang, R., Castel, A., Francois, R. (2009). "Serviceability Limit State criteria based on steel-concrete bond loss for corroded reinforced concrete in chloride environment." Materials and Structures., 42: 1407-1421.

Zhu, W., and François, R., Coronelli, D., Cleland, D. (2013). "Effect of corrosion of reinforcement on the mechanical behaviour of highly corroded RC beams.” Engineering Structures., 56: 544-554.

Zhu, W., and François, R. (2015). "Structural performance of RC beams in relation with the corroded period in chloride environment." Mater Struct., 47:1-13.

Zhu, W., and François, R. (2014). "Corrosion of the reinforcement and its influence on the residual structural performance of a 26-year-old corroded RC beam." Construction and Building Materials., 51: 461-472.

(1)

(1)

(1)


808

809

810

811

812

813

814

815

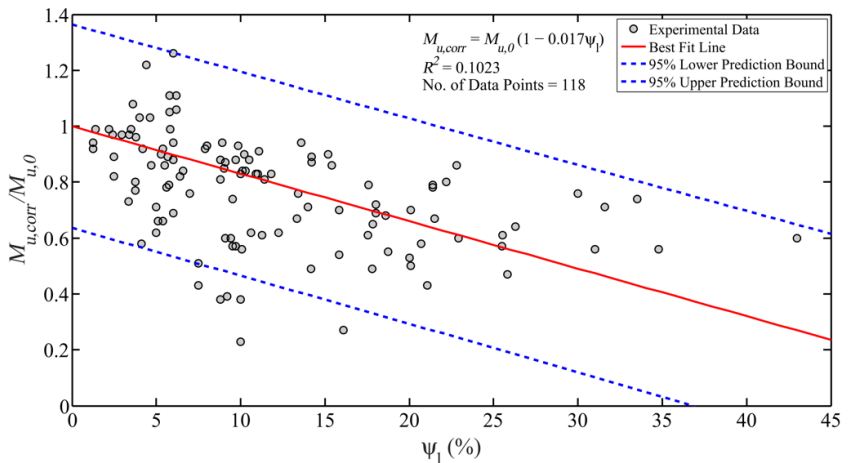

(a)

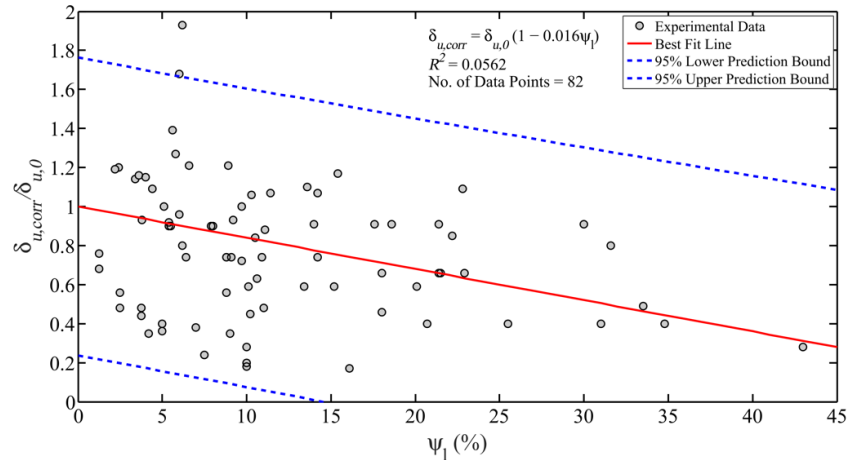

(b)

Fig. 1 Impact of corrosion on residual capacity of RC beams in flexure: (a) bending moment capacity, and (b) maximum deflection capacity

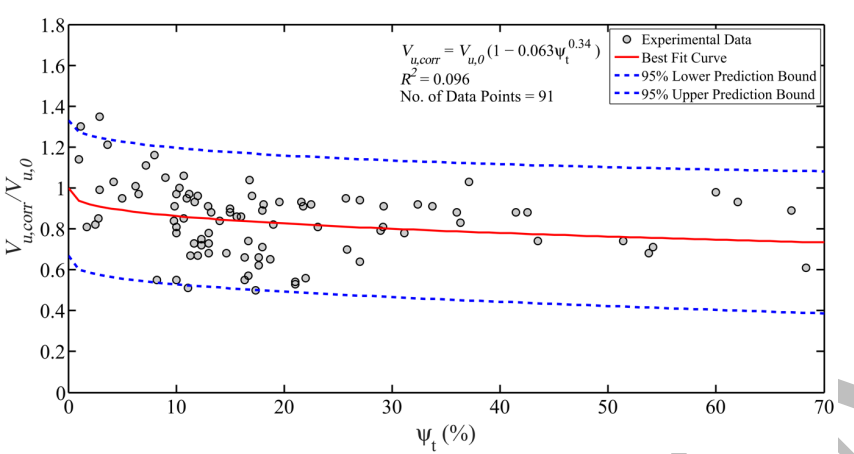

(a)

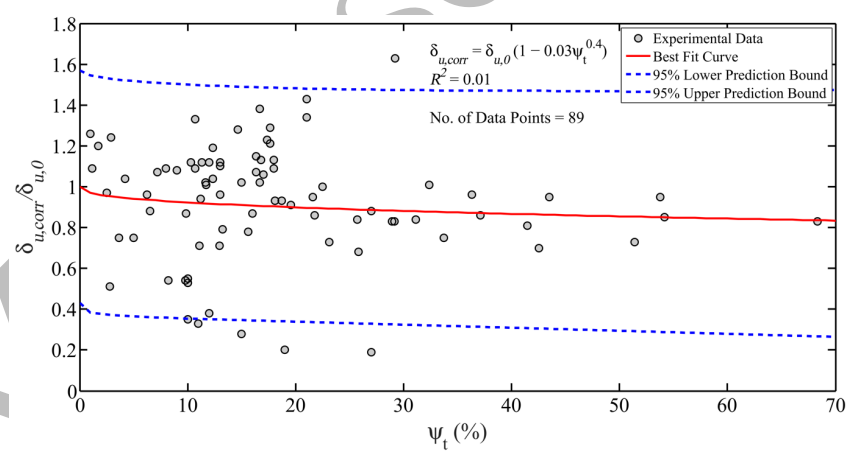

(b)

Fig. 2 Impact of corrosion on residual capacity of RC beams in shear: (a) shear capacity, and (b) maximum deflection capacity

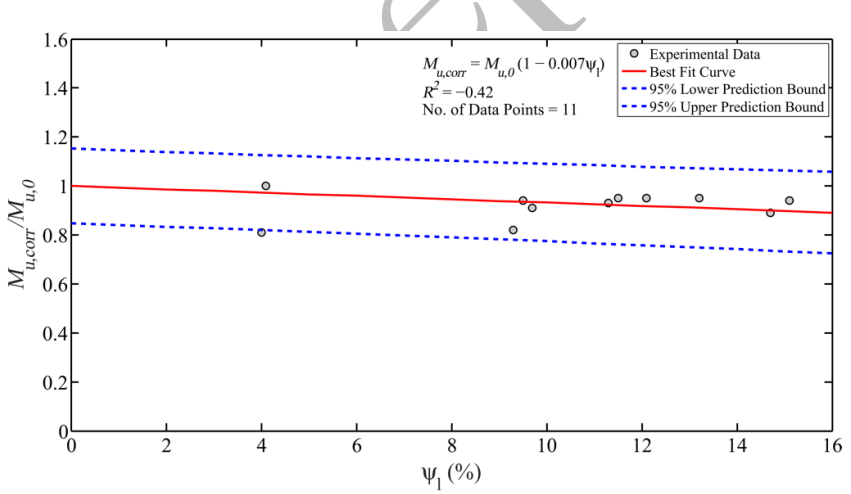

(a)

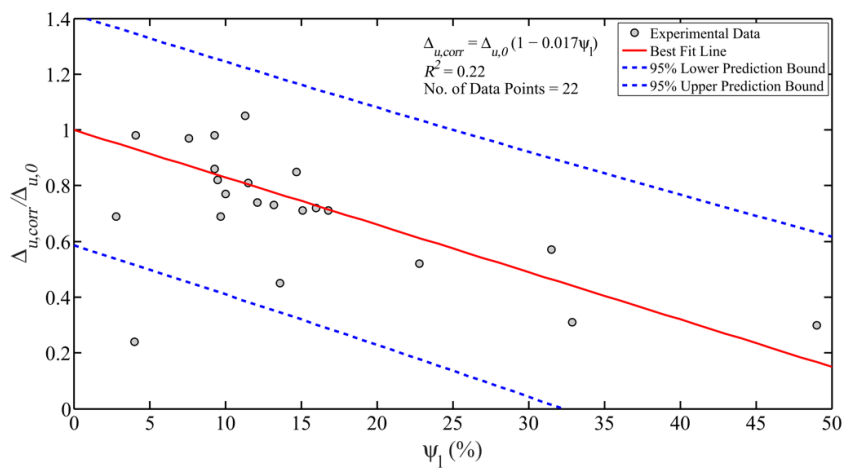

(b)

818 Fig. 3 Impact of corrosion on residual flexural capacity of circular RC columns: (a) ultimate bending moment capacity, and (b) maximum tip displacement capacity 
820

821

822 823

824

825

826

827

828

829

830

831

832

833

834

835

836

837

838

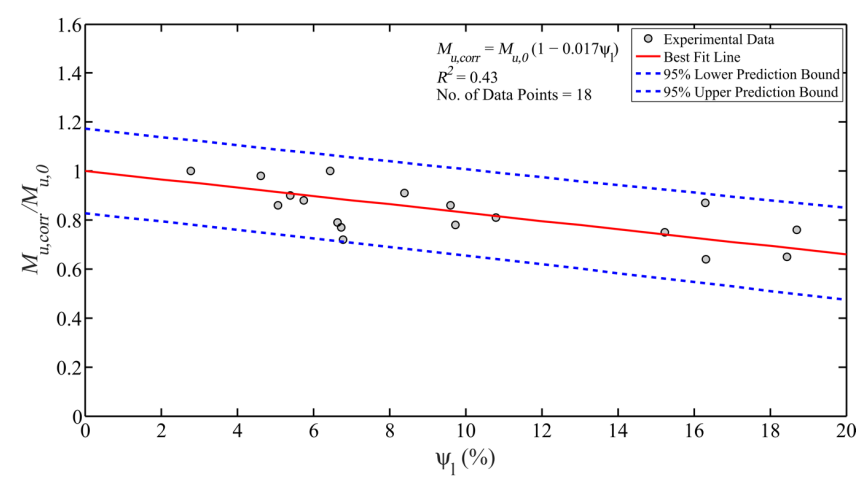

(a)

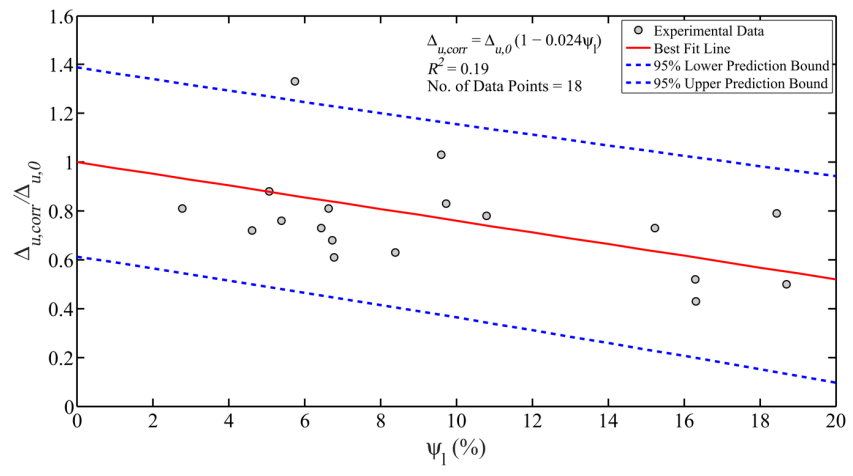

(b)

Fig. 4 Impact of corrosion on residual flexural capacity of rectangular RC columns: (a) ultimate bending moment capacity, and (b) maximum tip displacement capacity

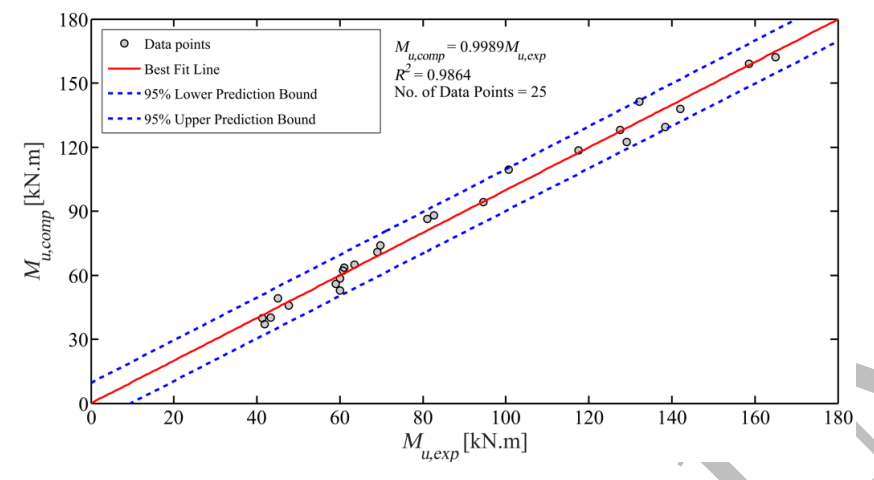

(a)

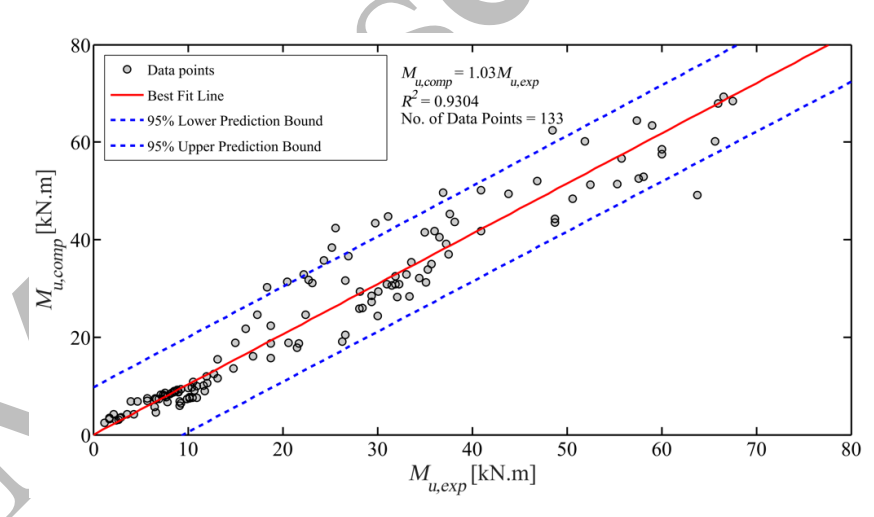

(b)

Fig. 5 Computational bending moment capacity of RC specimens versus corresponding experimental values: (a) rectangular columns and (b) flexural beams 


\begin{tabular}{|c|c|c|c|}
\hline Reference & $\begin{array}{c}\text { No. of } \\
\text { Specimens }\end{array}$ & $\begin{array}{c}\psi_{l} \\
(\%)\end{array}$ & Summary \\
\hline $\begin{array}{c}\text { Mangat \& } \\
\text { Elgarf (1999) }\end{array}$ & 13 & Up to $10 \%$ & $\begin{array}{l}\text { The flexural strength of beams reduced with increasing levels of } \\
\text { corrosion, primarily due to the breakdown of bond at the steel/concrete } \\
\text { interface. Flexural strength reduced more for beams corroded by the } \\
\text { higher rate of } 4 \mathrm{~mA} \cdot \mathrm{cm}^{-2} \text { than the beams corroded at } 2 \mathrm{~mA} \cdot \mathrm{cm}^{-2} \text {. } \\
\text { Deflection was not significantly affected by corrosion rate. }\end{array}$ \\
\hline $\begin{array}{l}\text { El Maaddawy et } \\
\text { al. }(2005 \mathrm{~b})\end{array}$ & 9 & Up to $32 \%$ & $\begin{array}{l}\text { The reduction of load-carrying capacity was almost proportional to the } \\
\text { reduction in the steel cross-sectional area due to corrosion. }\end{array}$ \\
\hline $\begin{array}{l}\text { Torres-Acosta et } \\
\quad \text { al. (2006) }\end{array}$ & 9 & Up to $16 \%$ & $\begin{array}{l}\text { Increased corrosion lead to a decrease in ultimate moment capacity and } \\
\text { maximum midspan displacement. Cracks developed more rapidly in dry, } \\
\text { rather than humid, environments. }\end{array}$ \\
\hline Du et al. (2007) & 18 & Up to $14 \%$ & $\begin{array}{l}\text { Corrosion caused over-reinforced beams to fail in a less brittle manner } \\
\text { and under-reinforced beams to fail in a less ductile manner. }\end{array}$ \\
\hline $\begin{array}{l}\text { Azad et al. } \\
\text { (2007) }\end{array}$ & 28 & Up to $31 \%$ & $\begin{array}{l}\text { Increasing corrosion activity index, } \mathrm{I}_{\text {corr }} \mathrm{T} \text {, was the key measure of metal } \\
\text { loss and flexural strength loss. Beams with low values of } \mathrm{I}_{\text {corr }} \mathrm{T} \text { could still } \\
\text { be predicted just by calculating cross-sectional area loss of the tensile } \\
\text { reinforcement. }\end{array}$ \\
\hline $\begin{array}{l}\text { Cairns et al. } \\
(2008)\end{array}$ & 14 & Up to $6 \%$ & $\begin{array}{l}\text { Strength appeared to increase as corrosion increased. This is believed to } \\
\text { be due to the increase in anchorage capacity. }\end{array}$ \\
\hline $\begin{array}{l}\text { Zhang et al. } \\
\quad(2009) \\
\text { Castel et al. } \\
\quad(2000)\end{array}$ & 3 & Up to $18 \%$ & $\begin{array}{l}\text { Deflection was found to be more sensitive to pitting attacks rather than } \\
\text { the ultimate load due to the influence of the tension steel-concrete bond } \\
\text { reduction. Ultimate load capacity decreased with increasing rebar mass } \\
\text { loss. }\end{array}$ \\
\hline $\begin{array}{l}\text { Azad et al. } \\
\quad(2010)\end{array}$ & 42 & Up to $26 \%$ & $\begin{array}{l}\text { For lower values of } I_{\text {corr }} T\left(\mathrm{~mA} \text {.days. } \mathrm{cm}^{-2}\right) \text {, the residual flexural strength of } \\
\text { beams was able to be predicted fairly accurately by considering only the } \\
\text { area loss of the tension reinforcement. }\end{array}$ \\
\hline $\begin{array}{l}\text { Ou \& Chen } \\
\text { (2014) }\end{array}$ & 7 & Up to $35 \%$ & $\begin{array}{l}\text { Beams were able to maintain a satisfactory ductile flexural behaviour with } \\
\text { plastic rotation capacities larger than } 3 \% \text {, up to } 6 \% \text { mass loss. }\end{array}$ \\
\hline $\begin{array}{l}\text { Zhu \& François } \\
\qquad(2015)\end{array}$ & 2 & & $\begin{array}{l}\text { Loss of one percent of the cross-section of the tensile bar corresponded to } \\
\text { approximately one percent reduction in the yield capacity of the corroded } \\
\text { beams. }\end{array}$ \\
\hline Yu et al. (2015) & 3 & & $\begin{array}{l}\text { The control beam failed by crushing of the compressive concrete followed } \\
\text { by tensile rebar rupture, whereas corroded beams failed by cover spalling } \\
\text { and failure of a tensile bar. }\end{array}$ \\
\hline $\begin{array}{l}\text { Al-Saidy et al. } \\
\quad(2016)\end{array}$ & 6 & & $\begin{array}{l}\text { Corroded beams experienced similar moment capacity losses, however, } \\
\text { beams without stirrups experienced much larger decreasing in mid-span } \\
\text { displacement. }\end{array}$ \\
\hline
\end{tabular}




\begin{tabular}{|c|c|c|c|}
\hline Reference & $\begin{array}{l}\text { No. of } \\
\text { Specimens }\end{array}$ & $\begin{array}{c}\psi_{t} \\
(\%)\end{array}$ & Summary \\
\hline $\begin{array}{l}\text { Rodriquez et } \\
\text { al. (1997) }\end{array}$ & 30 & $\begin{array}{l}\text { Up to } \\
22 \%\end{array}$ & $\begin{array}{l}\text { Beams with different tensile and compressive reinforcement were tested. } \\
\text { Some beams with only bottom reinforcement corrosion were tested. More } \\
\text { highly corroded beams failed by shear or loss of bond compared to low } \\
\text { corrosion beams which failed via ductile means such as bending. }\end{array}$ \\
\hline $\begin{array}{l}\text { Higgins \& } \\
\text { Farrow III } \\
\quad(2006)\end{array}$ & 8 & $\begin{array}{l}\text { Up to } \\
34 \%\end{array}$ & $\begin{array}{l}\text { Maximum shear decreases with increasing stirrup spacing and rebar mass } \\
\text { loss, as does maximum displacement. More localised concrete cover damage } \\
\text { for wider spaced stirrups. }\end{array}$ \\
\hline $\begin{array}{l}\text { Suffern et al. } \\
\qquad(2010)\end{array}$ & 12 & $\begin{array}{l}\text { Up to } \\
19 \%\end{array}$ & $\begin{array}{l}\text { Shear strength decreased with increasing corrosion. Increased corrosion leads } \\
\text { to large crack widths. Shear strength reduced for beams with smaller span-to- } \\
\text { depth ratios. }\end{array}$ \\
\hline $\begin{array}{l}\text { Xia et al. } \\
(2011)\end{array}$ & 18 & $\begin{array}{l}\text { Up to } \\
54 \%\end{array}$ & $\begin{array}{l}\text { Average and maximum crack widths can be used as an indicator of how much } \\
\text { corrosion the beams have experienced. The mode of failure changed from } \\
\text { concrete crushing to stirrup failure with increasing corrosion. }\end{array}$ \\
\hline $\begin{array}{l}\text { Alaskar } \\
(2013)\end{array}$ & 12 & $\begin{array}{l}\text { Up to } \\
16 \%\end{array}$ & $\begin{array}{l}\text { Shear strength was shown to decrease with increasing corrosion except for } \\
\text { smooth stirrups with corrosion levels below } 8 \% \text {. }\end{array}$ \\
\hline $\begin{array}{l}\text { Zhu et al. } \\
\text { (2013) }\end{array}$ & 4 & $\begin{array}{l}\text { Up to } \\
67 \%\end{array}$ & $\begin{array}{l}\text { Loss of one percent of the cross-section of the tensile bar corresponded to } \\
\text { approximately one percent reduction in the yield capacity of the corroded } \\
\text { beams. }\end{array}$ \\
\hline $\begin{array}{l}\text { Khan et al. } \\
\text { (2014) }\end{array}$ & 3 & & $\begin{array}{l}\text { The mechanical behaviour of deep beams was studied. The corrosion was } \\
\text { natural. Corrosion was found to have no effect on the failure mechanism of } \\
\text { these deep beams. }\end{array}$ \\
\hline Wang (2015) & & $\begin{array}{l}\text { Up to } \\
68 \%\end{array}$ & $\begin{array}{l}\text { Corrosion of less than } 10 \% \text { was found to do not have s significant effect on } \\
\text { the deterioration of shear strength. Corrosion was not found to effect failure } \\
\text { mode but did reduce the number of cracks at failure and encourage early } \\
\text { stirrup rupture. }\end{array}$ \\
\hline $\begin{array}{l}\text { El-Sayed et } \\
\text { al. }(2016)\end{array}$ & 9 & $\begin{array}{l}\text { Up to } \\
18 \%\end{array}$ & $\begin{array}{l}\text { Three tests with variable stirrup spacing, } 100 \mathrm{~mm}, 150 \mathrm{~mm} \text {, and } 200 \mathrm{~mm} \text {. Three } \\
\text { beams per test were set up with corrosion levels approximately } 0 \%, 10 \% \text {, and } \\
20 \% \text {. Shear compression was more common in low corroded specimens } \\
\text { whereas stirrup rupture more common in high. }\end{array}$ \\
\hline $\begin{array}{l}\text { Ye et al. } \\
(2018)\end{array}$ & 13 & $\begin{array}{l}\text { Up to } \\
27 \%\end{array}$ & $\begin{array}{l}\text { Increased corrosion lead to rapid decrease in shear strength and ductility. } \\
\text { Failure mode shifted from bending to shear with increasing corrosion. }\end{array}$ \\
\hline
\end{tabular}


Table 3. Summary of experimental researches on corrosion damaged columns under pure compression loading

\begin{tabular}{|c|c|c|c|}
\hline Reference & $\begin{array}{c}\text { No. of } \\
\text { Specimens }\end{array}$ & $\begin{array}{l}\psi_{t} \\
(\%)\end{array}$ & Summary \\
\hline $\begin{array}{c}\text { Bae et al. } \\
(2005)\end{array}$ & 3 & Up to $49 \%$ & $\begin{array}{l}\text { Circular columns were tested. Axial strain } \\
\text { reduced with increasing corrosion. } \\
\text { Compression strength wasn't affected until } \\
\text { very high corrosion levels occurred. }\end{array}$ \\
\hline $\begin{array}{c}\text { Vu et al. } \\
(2017)\end{array}$ & 24 & Up to $25 \%$ & $\begin{array}{l}\text { Square columns were tested. As the corrosion } \\
\text { level increased, both ductility and strength of } \\
\text { the corroded confined concrete severely } \\
\text { decrease. }\end{array}$ \\
\hline $\begin{array}{c}\text { Vu et al. } \\
(2017)\end{array}$ & 12 & Up to $33 \%$ & $\begin{array}{l}\text { Circular columns were tested. Similar } \\
\text { volumetric ratios of transverse reinforcement } \\
\text { and corrosion levels gave rise to comparable } \\
\text { results, regardless of the columns shape. }\end{array}$ \\
\hline
\end{tabular}

The detailed data is available in the online downloadable supplementary file (Exp data.xlsx) provided with the paper.

Table 4. Summary of experimental studies on flexural behaviour of circular corroded RC columns

\begin{tabular}{|c|c|c|l|}
\hline Reference & $\begin{array}{c}\text { No. of } \\
\text { Specimens }\end{array}$ & $\begin{array}{c}\boldsymbol{\psi}_{l} \\
\mathbf{( \% )}\end{array}$ & Summary \\
\hline $\begin{array}{c}\text { Aquino \& } \\
\begin{array}{c}\text { Hawkins } \\
(2007)\end{array}\end{array}$ & 2 & Up to 4\% & $\begin{array}{l}\text { A corrosion level of } 4 \% \text { resulted in a } 76 \% \\
\text { reduction in maximum displacement, as well } \\
\text { as a 19\% reduction in flexural strength. The } \\
\text { axial load was zero. }\end{array}$ \\
\hline $\begin{array}{c}\text { Ma et al. } \\
(2011)\end{array}$ & 13 & Up to 15\% & $\begin{array}{l}\text { Higher axial loads lead to more brittle failures. } \\
\text { Larger corrosion levels and axial force } \\
\text { resulted in worse seismic behaviour, stiffness, } \\
\text { ductility, and energy dissipation. }\end{array}$ \\
\hline
\end{tabular}

The detailed data is available in the online downloadable supplementary file (Exp data.xlsx) provided with the paper.

Table 5. Summary of experimental researches on flexural behaviour of corrosion damaged rectangular RC columns

\begin{tabular}{|c|c|c|}
\hline Reference & $\begin{array}{c}\text { No. of } \\
\text { Specimens }\end{array}$ & Summary \\
\hline $\begin{array}{c}\text { Lee et al. } \\
(2003)\end{array}$ & 4 & $\begin{array}{c}\text { Increased corrosion leads to a decline in strength and deformability due to the loss in } \\
\text { rebar cross-sectional area, loss of bond between the steel and concrete, and decline in } \\
\text { restraining effect due to the spalling of concrete cover. }\end{array}$ \\
\hline $\begin{array}{c}\text { Li et al. } \\
(2009)\end{array}$ & 4 & $\begin{array}{c}\text { Corrosion reduced flexural strength, more so for the higher axial loads. Ductility and } \\
\text { displacement showed no strong trend for the four specimens. }\end{array}$ \\
\hline $\begin{array}{c}\text { Meda et al. } \\
(2014)\end{array}$ & 2 & $\begin{array}{c}\text { Corrosion resulted in a large decrease in ductility and flexural strength, as well as a } \\
\text { decrease in } \mathrm{M}_{\mathrm{y}} / \mathrm{M}_{\mathrm{u}} \text {. }\end{array}$ \\
\hline $\begin{array}{c}\text { Guo et al. } \\
(2015 \mathrm{~b})\end{array}$ & 4 & $\begin{array}{c}\text { Higher corrosion levels lead to worse seismic behaviour, poorer strength and stiffness, } \\
\text { decreased ductility and displacement, and lower energy dissipation capacity. }\end{array}$ \\
\hline $\begin{array}{c}\text { Yang et al. } \\
(2016)\end{array}$ & 5 & $\begin{array}{c}\text { Columns with equal axial force and increasing corrosion were tested. Increased } \\
\text { corrosion resulted in decreased flexural strength, deflection, and ductility. Flexural } \\
\text { strength was not affected much until the maximum corrosion reached 10\%. }\end{array}$ \\
\hline $\begin{array}{c}\text { Li et al. } \\
(2018)\end{array}$ & 6 & $\begin{array}{c}\text { Flexural strength, ductility, and maximum displacement decreased with increasing } \\
\text { corrosion. Flexural strength and displacement were affected more with a larger axial } \\
\text { force, whereas, the opposite occurred for ductility. }\end{array}$ \\
\hline
\end{tabular}

